\title{
Passage of large plastic particles through the digestive tract of lactating and dry cows ${ }^{*}$
}

\author{
J. Třináctý1, M. Šimek ${ }^{1}$, L. Zeman² and J. Harazim $^{3}$ \\ 'Research Institute of Animal Nutrition, Ltd. \\ Videňská 699, 69123 Pohořlice, Czech Republic \\ ${ }^{2}$ Mendel University of Agriculture and Forestry \\ Zemédèská 1, 61300 Brno, Czech Republic \\ ${ }^{3}$ Central Institute for Supervising and Testing in Agriculture \\ Jaselská 16, 746 01 Opava, Czech Republic
}

(Received 23 September 1998; accepted 19 March 1999)

\begin{abstract}
In five trials carried out on two lactating and two dry cows three sets of particle sizes were used: in the first set particles with a diameter of $9 \mathrm{~mm}$ and length of $4,6,8$ and $10 \mathrm{~mm}$, in the second set particle sizes of $8 / 8,11 / 11,14 / 14$ and $17 / 17$ (diameter/length) $\mathrm{mm}$, and the third set $8 / 8,9 / 9,10 / 10,11 /$ 11 and $12 / 12 \mathrm{~mm}$ particles. In the first set the lactating cows had a significantly higher mean recovery $(97.8$ vs $75.9 \%)$ and a significantly shorter total tract mean retention time (TMRT) $(53.0$ vs $96.6 \mathrm{~h}$ ) than the dry cows $(\mathrm{P}<0.05)$. In the second trial with lactating cows the main differences in recovery were found between $11 / 11$ and $14 / 14 \mathrm{~mm}$ particles, significant at $48 \mathrm{~h}$ after administration $(63.8 \mathrm{vs}$ $31.3 \% ; \mathrm{P}<0.05$ ). Regurgitation of $17 / 17 \mathrm{~mm}$ particles was $27.5 \%$ in lactating cows and $80 \%$ in dry cows in the course of $384 \mathrm{~h}$. In the third set did not yield significant results, except $36 \mathrm{~h}(\mathrm{P}<0.05)$ after placing. It is concluded that relatively good recovery and TMRT can be achieved in lactating cows with plastic particles of a size larger than $11 / 11 \mathrm{~mm}$ but smaller than $14 / 14 \mathrm{~mm}$.
\end{abstract}

KEY WORDS: plastic particles, passage, recovery, retention time, cow

\section{INTRODUCTION}

Particle passage through the digestive tract of cattle depends on the specific gravity of the particles. The optimum density of plastic particles was established by King and Moore (1957). Their trials with steers showed that the highest speed of

* Supported by NAZV Agency, Project No 9600027197-15 
particle passage was achieved with a particle density of about $1.2 \mathrm{~g} / \mathrm{cm}^{3}$. Campling and Freer (1962) found that the lowest ruminal mean retention time was achieved with a particle specific gravity of $1.1-1.2 \mathrm{~g} / \mathrm{cm}^{3}$. Stetter Neel et al. (1995) reported that the ruminal passage rate of 1 and $3 \mathrm{~mm}$ inert particles grew (from 0.68 to 5.79 $\% / \mathrm{h}$ ) when their specific gravity increased from 0.9 to $1.32 \mathrm{~g} / \mathrm{cm}^{3}$. From the above values, the ideal range of $1.2-1.3 \mathrm{~g} / \mathrm{cm}^{3}$ was derived for our plastic particles.

Larger particles pass more slowly through the digestive tract of cattle. This was confirmed by trials performed by Moore et al. (1992) and Mambrini and Peyraud (1997) where ground hay showed shorter total tract mean retention time (TMRT) than particles of long hay. Similar results were found with plastic particles. In a trial with dry cows, Campling and Freer (1962) related the 3.2, 4.0 and $4.8 \mathrm{~mm}$ size of particles directly to TMRT $(80,86$ and $91 \mathrm{~h})$. When cylindrical nylon particles of 1 , 3 and $5 \mathrm{~mm}$ length were placed in the rumen of steers by Prigge et al. (1990), ruminal retention time was $17.4,20.7$ and $61.36 \mathrm{~h}$.

The passage of large plastic particles has not been sufficiently tested. Welch and Smith (1978) fed steers with 5, 10, 15 and $20 \mathrm{~mm}$ rubber strips and achieved $0.9 \%$ recovery of nonruminated $20 \mathrm{~mm}$ particles. Ehle and Stern (1986) introduced $3.2,6.4$ and $12.7 \mathrm{~mm}$ spheres into the rumen of heifers achieving recovery of 78.2 , 79.5 and $68.8 \%$.

In 1995 the nylon capsule method was presented for the first time (Třináctý et al., 1995a,b). The presented method was based on $10 \mathrm{~mm}$ nylon capsules made of nylon cloth filled with feed samples and orally inserted into the animal. The questions remained which is the optimum capsule size to use and which maximum size of particles will pass through the digestive tract of cattle with satisfactory recovery and total tract mean retention time (TMRT). The plastic particles in this study were tested as a model for nylon capsules. Because the passage of particles depends on dry matter (DM) intake, the trials were conducted on dry (with smaller DM intake) and lactating cows (with higher DM intake). The aim was to evaluate the passage of large plastic particles given to lactating and dry cows.

\section{MATERIAL AND METHODS}

\section{Animals}

Two lactating crossbred cows and two dry crossbred cows were used (Czech Pied $>75 \% \times$ Black Friesian $<25 \%$ ). The liveweight of the lactating cows at the beginning of the trials was 550 and $535 \mathrm{~kg}$. The diet consisted of $20 \mathrm{~kg}$ of maize silage with $29.8 \%$ dry matter (DM), $4 \mathrm{~kg}$ of lucerne hay and $6 \mathrm{~kg}$ of a mixture (\%: maize meal 25 , soyabean meal 23 , oat meal 17 , wheat meal 12 , lucerne meal 12 , wheat bran 8 , dicalcium phosphate 2.5 , and sodium chloride 0.5 ). The diet was 
calculated according to the performance of the cows ( $\breve{C S N} 467070$ ), components of the ration were fed separately. The mean daily consumption by the two lactating cows during the trials was $14.83 \mathrm{~kg}$ of DM, $2.54 \mathrm{~kg}$ of crude protein and $3.01 \mathrm{~kg}$ of crude fibre with small refusals $(0.28 \mathrm{~kg}$, s.e. 0.14 , respectively, $0.22 \mathrm{~kg}$, s.e. 0.07$)$. The mean milk yield was 12.48 (s.e. 0.13 ) and $15.01 \mathrm{~kg}$ (s.e. 0.14 ), respectively.

The liveweight of the dry cows at the beginning of the trials was 525 and $510 \mathrm{~kg}$. The diet consisted of $6 \mathrm{~kg}$ of lucerne hay and $1.4 \mathrm{~kg}$ of a mixture (\%: barley meal 32 , maize meal 32, wheat meal 32, mineral supplement 2 and sodium chloride 2 ). With dry cows no refusals were found, the mean daily feed intake being $6.43 \mathrm{~kg}$ of $\mathrm{DM}, 1.17 \mathrm{~kg}$ of crude protein and $1.64 \mathrm{~kg}$ of crude fibre. The diets of the lactating and the dry cows were fed twice daily, at $5.00 \mathrm{a} . \mathrm{m}$. and 3.00 p.m.

\section{Plastic particles}

Cylindrical plastic particles were used. They were made of polypropylene with limestone as the filler (Chirana, Brno). The specific gravity of the particles was $1.25 \pm 0.05 \mathrm{~g} / \mathrm{cm}^{3}$. In five trials three sets of particle sizes were used: in trials $1 \mathrm{~L}$ (lactating cows) and 1D (dry cows) the particle diameter was $9 \mathrm{~mm}$ and the height of the cylinders (i. e. the length of the particles) was $4,6,8$ and $10 \mathrm{~mm}$. Fifty particles of each size (together 200 pieces) were given to one cow at one time. The particles in $1 \mathrm{~L}$ and $1 \mathrm{D}$ trials were given in two periods.

\section{Experiment with cows}

In trials $2 \mathrm{~L}$ and 2D 8/8,11/11,14/14 and $17 / 17 \mathrm{~mm}$ (diameter/length) particles were used. The total number of particles simultaneously given to one cow was 80 , with 20 particles of each size. Except for particles 17/17, which were given only to the lactating cows in the first period, the remaining particles were given in two periods.

In trial $3 \mathrm{~L}$ a set of $8 / 8,9 / 9,10 / 10,11 / 11$ and $12 / 12 \mathrm{~mm}$ particles was applied in four periods. Thirty pieces of each size ( 150 particles in all) were introduced into one cow at one time.

Each application and cow had its own particle colour. Plastic particles were administered orally by the "balling gun" device (Corio, 1976) after feeding at 8.00 a.m. as a paper bolus. Excrements were collected into pots within the $24 \mathrm{~h}$ service. The collection intervals were $12 \mathrm{~h}$ in the first 3 days and $24 \mathrm{~h}$ in the following days with the lactating cows, and $24 \mathrm{~h}$ in the dry cows.

One period lasted $168 \mathrm{~h}$ in the lactating cows (except for trial $2 \mathrm{~L}$, where it was $384 \mathrm{~h}$ ) and $384 \mathrm{~h}$ in the dry cows. The interval between applications of particles was generally 21 days, except for trial $3 \mathrm{~L}$, where it was 14 days. Excrements were washed under running water using a $4 \mathrm{~mm}$ screen. The regurgitated particles were found by the 24 -h service near the forelegs of the animals. 
The results were evaluated by multifactor analysis of variance using Statgraphic version 5.0 software; the sources of variability were the following factors: size of particles, period, cow and time interval. TMRT was calculated according to Thielemans et al. (1978) by means of the following formula:

$$
\text { TMRT }=\Sigma\left(Q_{t} \times t \times d t\right) / \Sigma\left(Q_{t} \times d t\right)
$$

where $Q_{1}$ the quantity of particles in faeces found during the faecal collection interval, the time interval after particles application and $t$ the faecal collection interval.

\section{RESULTS}

The differences between the recovery and TMRT of the individual particle sizes in $1 \mathrm{~L}$ and $1 \mathrm{D}$ trials were not significant ( $\mathrm{P}>0.05$; Table 1). The differences between the total means of all particle size recoveries in lactating and dry cows combined were significant for all time intervals. At the time interval of $192 \mathrm{~h}$ it was 97.8 vs $75.9 \%(\mathrm{P}<0.05)$. In the dry cows, the particle passage was significantly slower $(\mathrm{P}<0.05), 192 \mathrm{~h}$ after application TMRT was $53.0 \mathrm{~h}$ in the lactating cows vs $96.6 \mathrm{~h}$ in the dry cows $(\mathrm{P}<0.05)$. The results of the $1 \mathrm{~L}$ and $1 \mathrm{D}$ trials are also shown in Figure 1. The courses of the cumulative recovery of particles are ordered according to their size in the lactating and the dry cows.

Based on the results of $1 \mathrm{~L}$ and $1 \mathrm{D}$ trials a larger range of particle sizes was selected in trials $2 \mathrm{~L}$ and $2 \mathrm{D}$. Table 2 shows that with the lactating cows no significant differences occurred ( $P>0.05$ ) between particles $8 / 8$ and $11 / 11$. Significantly lower recovery $(\mathrm{P}<0.05)$ was found with the $14 / 14$ particles after 48,72 and $96 \mathrm{~h}$,

TABLE 1

Mean cumulative recovery (\%) and TMRT (h) of 4/9,6/9,8/9 and 10/9 mm particles ${ }^{1}$ in $1 \mathrm{~L}$ and 1D trials

\begin{tabular}{|c|c|c|c|c|c|c|c|c|c|c|}
\hline \multirow{2}{*}{ Hours } & \multicolumn{4}{|c|}{ Lactating cows (trial 1L) } & \multicolumn{4}{|c|}{ Dry cows (trial 1D) } & \multicolumn{2}{|c|}{ Total mean } \\
\hline & $4 / 9$ & $6 / 9$ & $8 / 9$ & $10 / 9$ & $4 / 9$ & $6 / 9$ & $8 / 9$ & $10 / 9$ & $1 \mathrm{~L}$ & $1 \mathrm{D}$ \\
\hline 24 & 4.0 & 7.0 & 5.0 & 5.5 & 0.0 & 0.0 & 0.0 & 0.0 & 5.4 & 0.0 \\
\hline 48 & 58.5 & 57.5 & 60.5 & 63.5 & 0.5 & 0.6 & 0.0 & 0.0 & $60.0^{a}$ & $0.3^{\mathrm{t}}$ \\
\hline 72 & 87.0 & 89.0 & 85.5 & 81.0 & 33.0 & 32.6 & 26.1 & 25.2 & $85.6^{\mathrm{a}}$ & $29.2^{\mathrm{b}}$ \\
\hline 96 & 90.0 & 92.0 & 88.5 & 87.0 & 49.0 & 49.7 & 47.9 & 40.5 & $89.4^{\mathrm{a}}$ & $46.8^{b}$ \\
\hline 192 & 98.5 & 99.0 & 97.5 & 96.0 & 84.5 & 76.9 & 73.3 & 69.0 & $97.8^{a}$ & $75.9^{b}$ \\
\hline $384^{2}$ & - & - & - & - & 94.9 & 87.7 & 86.3 & 80.0 & - & 87.2 \\
\hline TMRT192 h² & 50.5 & 50.0 & 55.1 & 56.5 & 98.4 & 93.7 & 97.6 & 96.5 & $53.0^{\mathrm{a}}$ & $96.6^{\mathrm{b}}$ \\
\hline TMRT $384 h^{2}$ & - & - & - & - & 115.6 & 117.7 & 132.3 & 130.2 & - & 124.0 \\
\hline
\end{tabular}

\footnotetext{
' length/diameter ratio

${ }^{2}$ TMRT calculated up to $192 \mathrm{~h}$ after application (or $384 \mathrm{~h}$, respectively) $\mathrm{a}, \mathrm{b}-\mathrm{P}<0.05$
} 


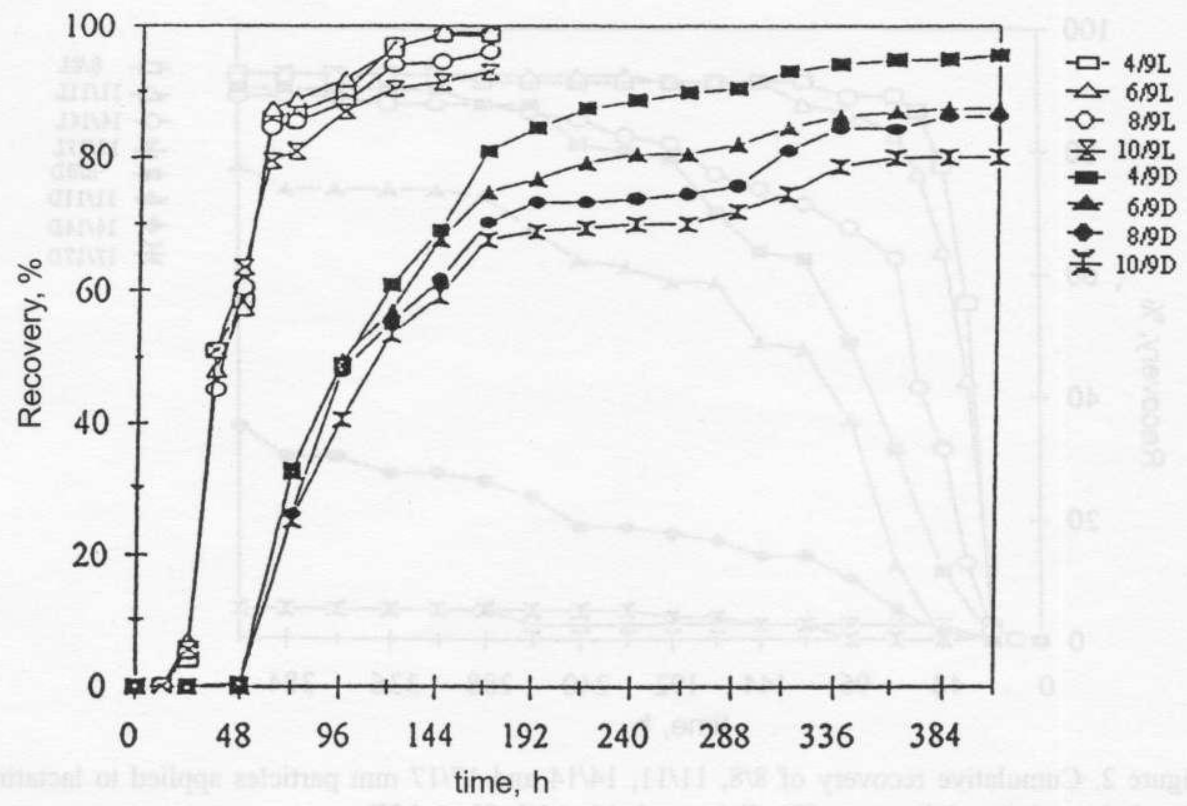

Figure 1. Cumulative recovery of $4 / 9,6 / 9,8 / 9$ and $10 / 9 \mathrm{~mm}$ particles applied to lactating $(\mathrm{L}$ - dark marks) and dry (D - light marks) cows in trials $1 \mathrm{~L}$ and $1 \mathrm{D}$

TABLE 2

Mean cumulative recovery (\%) and TMRT (h) of $8 / 8,11 / 11,14 / 14$ and $17 / 17 \mathrm{~mm}^{2}$ articles ${ }^{1}$ in $2 \mathrm{~L}$ and 2D trials

\begin{tabular}{|c|c|c|c|c|c|c|c|c|}
\hline \multirow{2}{*}{ Hours } & \multicolumn{4}{|c|}{ Lactating cows (trial $2 \mathrm{~L})^{2}$} & \multicolumn{4}{|c|}{ Dry cows (trial $2 \mathrm{D})^{2}$} \\
\hline & $8 / 8$ & $11 / 11$ & $14 / 14$ & $17 / 17$ & $8 / 8$ & $11 / 11$ & $14 / 14$ & $17 / 17$ \\
\hline 24 & 2.5 & 2.5 & 1.3 & $0.0^{3}$ & 0.0 & 0.0 & 0.0 & 0.0 \\
\hline 48 & $77.5^{\mathrm{a}}$ & $63.8^{\mathrm{a}}$ & $31.3^{\mathrm{b}}$ & 2.5 & 11.3 & 0.0 & 1.3 & 0.0 \\
\hline 72 & $88.8^{\mathrm{a}}$ & $82.5^{\mathrm{ab}}$ & $62.5^{\mathrm{b}}$ & 2.5 & 31.3 & 12.5 & 5.0 & 0.0 \\
\hline 96 & $88.8^{\mathrm{a}}$ & $86.3^{\mathrm{ab}}$ & $67.5^{\mathrm{b}}$ & 2.5 & $48.8^{\mathrm{a}}$ & $36.3^{\text {ab }}$ & $10.0^{\mathrm{b}}$ & 0.0 \\
\hline 192 & 91.3 & 91.3 & 81.3 & 2.5 & $78.8^{\mathrm{a}}$ & $58.8^{\mathrm{a}}$ & $17.5^{\mathrm{b}}$ & 3.8 \\
\hline 384 & 92.5 & 92.5 & 88.8 & 5.0 & $90.0^{\mathrm{a}}$ & $73.8^{\mathrm{a}}$ & $30.0^{\mathrm{b}}$ & 5.0 \\
\hline TMRT $384 \mathrm{~h}$ & 47.0 & 53.8 & 95.6 & -4 & 115.8 & 132.7 & 170.7 & -4 \\
\hline
\end{tabular}

\footnotetext{
${ }^{1}$ length/diameter ratio

${ }^{2}$ particles $17 / 17$ were not included in the statistical evaluation

${ }^{3}$ in trial 2L particles $17 / 17$ were only applied in the first period

${ }^{4}$ TMRT was not calculated (see in the text)

$\mathrm{a}, \mathrm{b}-\mathrm{P}<0.05$
} 


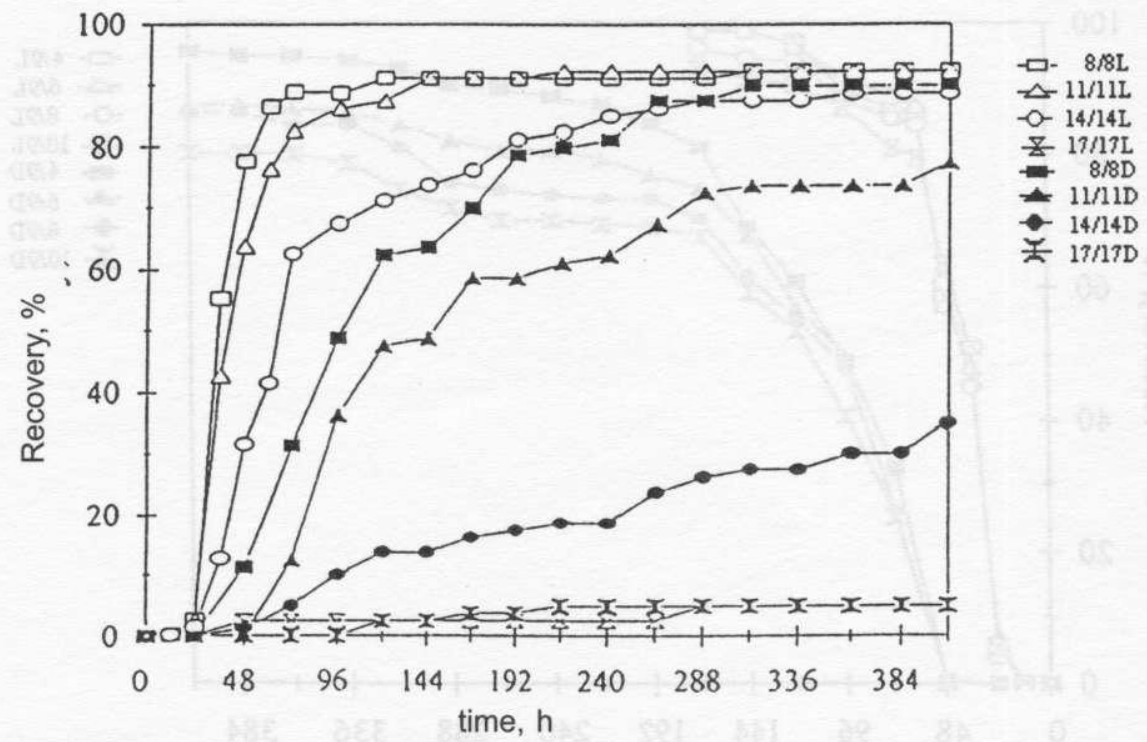

Figure 2. Cumulative recovery of $8 / 8,11 / 11,14 / 14$ and $17 / 17 \mathrm{~mm}$ particles applied to lactating $(\mathrm{L}$ - dark marks) and dry cows $(\mathrm{D}-$ light marks) in trials $2 \mathrm{~L}$ and $2 \mathrm{D}$

these differences can also be seen in Figure 2. This fact is in agreement with the TMRT values, which were 53.8 for the $11 / 11$ particles and increased to $95.6 \mathrm{~h}$ for the $14 / 14$ particles. The values for the $17 / 17 \mathrm{~mm}$ particles were excluded from statistical evaluation because in the lactating cows this size of particles was used only in the first period and their recovery as well as regurgitation (as mentioned below) was too small.

In the dry cows and trial 2D significant differences $(\mathrm{P}<0.05)$ were found between $8 / 8,11 / 11$ and $14 / 14$ particles for the 192 and $384 \mathrm{~h}$ time intervals. The recovery value of the $14 / 14$ particles was only $30.0 \%$ with a relatively high TMRT value of $170.7 \mathrm{~h}$. Also with the dry cows the obtained recovery of the $17 / 17$ particles was only $5.0 \%$.

When the recovery in trials $2 \mathrm{~L}$ and $2 \mathrm{D}$ (Table 2 ) is compared for the $384 \mathrm{~h}$ interval, one can see that the biggest difference between the lactating and the dry cows was found for the $14 / 14$ particles where the values were 88.8 and $30.0 \%$, respectively. The TMRT values of $8 / 8$ and $11 / 11$ particles in lactating cows were more than twice as small as in dry cows, which means that the particles passed through the digestive tract of lactating cows more than twice as fast. In the lactating cows the $14 / 14$ particles passed more quickly than the $8 / 8$ in the dry cows, the TMRT value being 95.6 vs $115.8 \mathrm{~h}$, respectively. 
TABLE 3

Mean cumulative regurgitation (\%) of $1 \mathrm{l} / 11,14 / 14$ and $17 / 17 \mathrm{~mm}$ particles' in 2L and 2D trials

\begin{tabular}{ccccccccc}
\hline \multirow{2}{*}{ Hours } & \multicolumn{3}{c}{ Lactating cows (trial 2L) } & & \multicolumn{3}{c}{ Dry cows (trial 2D) } \\
\cline { 2 - 5 } \cline { 7 - 9 } & $11 / 11$ & $14 / 14$ & $17 / 17$ & & $11 / 11$ & $14 / 14$ & $17 / 17$ \\
\hline 24 & 0.0 & 0.0 & $2.5^{2}$ & & $1.3^{\mathrm{a}}$ & $10.0^{\mathrm{ab}}$ & $23.8^{\mathrm{b}}$ \\
48 & 1.3 & 3.8 & 10.0 & & $2.5^{\mathrm{a}}$ & $31.3^{\mathrm{b}}$ & $42.5^{\mathrm{b}}$ \\
72 & 1.3 & 5.0 & 10.0 & & $2.5^{\mathrm{a}}$ & $32.5^{\mathrm{b}}$ & $46.3^{\mathrm{b}}$ \\
96 & 1.3 & 6.3 & 20.0 & & $3.8^{\mathrm{a}}$ & $32.5^{\mathrm{b}}$ & $50.0^{\mathrm{b}}$ \\
192 & 1.3 & 7.5 & 22.5 & & $5.0^{\mathrm{a}}$ & $36.3^{\mathrm{b}}$ & $71.3^{\mathrm{c}}$ \\
384 & 1.3 & 7.5 & 27.5 & & $5.0^{\mathrm{a}}$ & $40.0^{\mathrm{b}}$ & $80.0^{\mathrm{c}}$ \\
\hline
\end{tabular}

' length/diameter ratio

2 particles $17 / 17$ were only applied in the first period $\mathrm{a}, \mathrm{b}-\mathrm{P}<0.05$

In the $2 \mathrm{~L}$ and $2 \mathrm{D}$ trials particle regurgitation increased with increased particle size. There was a relatively low number of regurgitated particles in the lactating cows (Table 3); for the 11/11 particles it was only $1.3 \%$. The $17 / 17$ particles were regurgitated in $27.5 \%$. The dry cows showed considerably higher values of regurgitation; $40.0 \%$ for the $14 / 14$ particles and $80.0 \%$ for the $17 / 17$ ones $(\mathrm{P}<0.05)$.

Table 4 shows the results of the $3 \mathrm{~L}$ trial with lactating cows. Although the application was repeated four times and the particle sizes ranged from $8 / 8$ to $12 / 12$ $\mathrm{mm}$, the only significant differences in recovery were found with the $36 \mathrm{~h}$ interval $(\mathrm{P}<0.05)$. TMRT increased non significantly $(\mathrm{P}>0.05)$ from $40.3 \%$ for the $9 / 9$ particles to $47.6 \%$ for the $12 / 12$ particles.

TABLE 4 Mean cumulative recovery $(\%)$ and TMRT $(h)$ of $8 / 8,9 / 9,10 / 10,11 / 11$ and $12 / 12 \mathrm{~mm}$ particles ${ }^{1}$ in the 3L trial

\begin{tabular}{lcccccc}
\hline \multirow{2}{*}{ Hours } & \multicolumn{5}{c}{ Lactating cows (trial 3L) } & \multirow{2}{*}{$\begin{array}{c}\text { Total } \\
\text { mcan }\end{array}$} \\
\cline { 2 - 6 } & $8 / 8$ & $9 / 9$ & $10 / 10$ & $11 / 11$ & $12 / 12$ & 7.3 \\
\hline 24 & 8.3 & 8.8 & 10.8 & 2.9 & 5.4 & 51.9 \\
36 & $57.7^{\mathrm{a}}$ & $56.8^{\mathrm{a}}$ & $57.4^{\mathrm{a}}$ & $43.3^{\mathrm{b}}$ & $44.3^{\mathrm{b}}$ & 74.6 \\
48 & 80.3 & 78.4 & 73.9 & 69.8 & 70.7 & 91.5 \\
72 & 93.3 & 93.6 & 92.3 & 90.2 & 88.0 & 95.4 \\
96 & 95.8 & 96.6 & 94.8 & 96.5 & 93.1 & 98.2 \\
192 & 97.9 & 97.9 & 97.3 & 99.6 & 98.2 & 43.5 \\
\hline TMRT 192 h & 40.5 & 40.3 & 42.0 & 47.0 & 47.6 & \\
\hline
\end{tabular}

' length/diameter ratio

$\mathrm{a}, \mathrm{b}-\mathrm{P}<0.05$ 


\section{DISCUSSION}

In both lactating and dry cows recovery increased with the decreased plastic particle size. This is in agreement with the findings of Welch and Smith (1978) and Stetter Neel et al. (1995) who tested the influence of the plastic particle size on their recovery. For all the sets of particle sizes applied, TMRT was significantly higher for larger particles $(\mathrm{P}<0.05$, except for the $3 \mathrm{~L}$ trial), as found by Mambrini and Peyraud (1997) with feed particles and by Prigge et al. (1993) with plastic particles.

The influence of the feed intake level on the increase of the speed of the feed particle passage from the rumen was described by Okine and Mathison (1991). This effect leads to a decrease of TMRT, as found by Luginbuhl et al. (1994) with feed particles in steers, and by Rothfuss et al. (1997) in a trial with cows. Our trials have also confirmed this effect. For example, in lactating cows with a higher intake level (14.8 kg DM/day) the TMRT for the $14 / 14$ particles was $95.6 \mathrm{~h}$, while in dry cows with a lower intake level $(6.43 \mathrm{~kg} \mathrm{DM} /$ day) it was $170.7 \mathrm{~h}$.

There is little information in the literature about large particle passage through the digestive tract of cattle. Welch and Smith (1978) used polypropylene ribbon 20 $\mathrm{mm}$ in length, $2.5 \mathrm{~mm}$ in width and $0.008 \mathrm{~mm}$ in thickness with a density of $0.9 \mathrm{~g} / \mathrm{cm}^{3}$ and found only a small recovery of $0.9 \%$ of the nonruminated particles. These results are hardly comparable with our values because the particles were of a different shape and specific gravity. Ehle and Stern (1986) used $12.7 \mathrm{~mm}$ particles with a $1.34 \mathrm{~g} / \mathrm{cm}^{3}$ density. Their relatively low recovery $(68.8 \%)$ was probably caused by the low level of feed intake by heifers. Another limiting factor of large particle passage through the digestive tract can also be the size of the reticuloomasal orifice, which, according to Welch (1982), is larger than $20 \mathrm{~mm}$ in cattle.

Regurgitation of spheres $12.7 \mathrm{~mm}$ in size and with a $1.34 \mathrm{~g} / \mathrm{cm}^{3}$ density was evaluated in heifers by Ehle and Stern (1986), with a resulting value of $15.5 \%$. Their result is similar to our value achieved in the $2 \mathrm{D}$ trial with dry cows and 11/11 and $14 / 14$ particles. Our values were 5.0 and $40.0 \%$, respectively. The higher regurgitation by dry cows of all sizes of particles is probably related to the fact that the passage of all particles was quicker in the lactating cows. This influence was confirmed especially for the larger $14 / 14$ and $17 / 17$ particles, where regurgitation was 40.0 and $80.0 \%$, respectively, in dry cows.

We have noticed that the corresponding recoveries of $8 / 8$ and 11/11 particles in trials $2 \mathrm{~L}$ and $3 \mathrm{~L}$ were different (Tables 2 and 4 ). The recovery values were non significantly $(\mathrm{P}>0.05)$ higher for the $3 \mathrm{~L}$ trial in all time intervals. For example, in the $2 \mathrm{~L}$ trial the $8 / 8$ and $11 / 11$ particles showed 91.3 and $91.3 \%$ recovery in the interval of $192 \mathrm{~h}$ after administration, while in the $3 \mathrm{~L}$ trial it was 97.9 and $99.6 \%$, respectively. Because in $3 \mathrm{~L}$ larger amounts of similar particles were applied simultaneously, we assume that in this case the particles were mutually moved forward, or 
"raked", which increased recovery. This interaction was labeled with the working name of "rake effect".

\section{CONCLUSIONS}

It can be concluded that in lactating cows with a daily intake of $14-15 \mathrm{~kg}$ DM relatively good recovery and retention time can be achieved with plastic particles of a size larger than $11 / 11 \mathrm{~mm}$ but smaller than $14 / 14 \mathrm{~mm}$. The use of $17 / 17 \mathrm{~mm}$ and larger particles is not recommended because recovery is negligible and most of the particles are regurgitated. The administration of large plastic particles to dry cows showed substantially lower recovery and longer retention time.

\section{ACKNOWLEDGMENTS}

The authors would like to thank to L. Poláková, M. Bzduchová, M. Cee, V. Hlaváček, J. Kř́ž and Z. Laštovičková for their assistance in the research.

\section{REFERENCES}

Campling R.C., Freer M., 1962. Tthe effect of specific gravity and size on the mean time of retention of inert particles in the alimentary tract of the cow. Brit. J. Nutr. 16, 507-518

Corio N.N., Pat. U.S.A. 3934584. Balling gun. 27. 6. 1976

CSN 46 7070, 1982. Nutrient Resurements of Farm Animals (in Czech). Praha, pp. 49

Ehle F.R., Stern M.D., 1986. Influence of particle size and density on particulate passage through alimentary tract of Holstein heifers. J. Dairy Sci. $69,564-568$

King K.W., Moore W.E.C., 1957. Density and size as factors affecting passage rate of ingesta in the bovine and human digestive tracts. J. Dairy Sci. 40, 528-536

Luginbuhl J.M., Pond K.R., Burns J.C., 1994. Whole-tract digesta kinetics and comparison of techniques for the estimation of fecal output in steers fed Coastal Bermudagrass hay at four levels of intake. J. Anim. Sci. 72, 201-211

Mambrini M., Peyraud J.L., 1997. Retention time of feed particles and liquids in the stomachs and intestines of dairy cows. Direct measurement and calculations based on faecal collection. Rep. Nutr. Develop. 37, 427-442

Moore J.A., Pond K.R., Poore M.H., Goodwin T.G., 1992. Influence of model and marker on digesta kinetic estimates for sheep. J. Anim. Sci. 70, 3528-3540

Okine E.K., Mathison G.W., 1991. Effects of feed intake on particle distribution, passage of digesta, and extent of digestion in the gastrointestinal tract of cattle. J. Anim. Sci. 69, 3435-3445

Prigge E.C., Fox J.T., Jacquement N.A., Russell R.W., 1993. Influence of forage species and diet particle size on the passage of digesta and nylon particles from the reticulorumen of steers. $\mathrm{J}$. Anim. Sci. 71, 2760-2769

Prigge E.C., Stuthers B.A., Jacquemet N.A., 1990. Influence of forage diets on ruminal particle size, passage of digesta, feed intake and digestibility by steers. J. Anim. Sci. $68,4352-4360$ 
Rothfuss H., Südekum K.H., Stangassinger M., 1997. Ermittlung der Passage eines Markers im Verdauungstrakt von Milchkühen mit Hilfe unterschiedlicher Schätzverfahren: Einfluss von Laktationsstadium, Fütterungsniveau und Rationszusammensetzung. Arch. Anim. Nutr. 50, 43-61

Stetter Neel J.P., Prigge E.C., Townsend E.C., 1995. Influence of moisture content of forage on ruminal functional specific gravity and passage of digesta. J. Anim. Sci. 73, 3094-3102

Thielemans M.F., Francois E., Bodart C., Thewis A., 1978. Mesure du transit gastrointestinal chez le porc á l'aide des radiolanthanides. Comparison avec le mouton. Ann. Biol. Anim. Biochem. Biophys. 18 (2A), 237-243

Třináctý J., Svozil B., Šmek M., 1995a. Digestibility evaluation of neutral sugars from hemicellulose of alfalfa hay by nylon capsule method. In: 4th International Symposium on the Nutrition of Herbivores, Clermont-Ferrand. Ann. Zootech., Suppl. 44, p. 189

Třináctý J., Svozil B., Šimek M., Horák V., 1995b. Digestibility of dry matter, crude protein and organic matter of alfalfa evaluated by nylon capsule method. In: Book of Abstracts of the 46th Annual Meeting of EAAP, Prague (Czech Republic), p. 112

Welch J. G., 1982. Rumination, particle size and passage from the rumen. J. Anim. Sci. 54, 885-894 Welch J.G., Smith A.M., 1978. Particle sizes passed from rumen. J. Anim. Sci. 46, 309-312

\section{STRESZCZENIE}

\section{Przechodzenie dużych plastikowych cząstek przez przewód pokarmowy krów produkujących mleko i zasuszonych}

W pięciu doświadczeniach, przeprowadzonych na 2 krowach produkujących mleko i 2 zasuszonych, badano tempo przechodzenia plastikowych cząstek w zależności od ich wielkości: w pierwszej serii cząstki o średnicy $9 \mathrm{~mm}$ i dhugości 4,6,8 i $10 \mathrm{~mm}$, w drugjej 8/8,11/11, 14/14 i 17/17 mm (średnica/długość) i w trzeciej serii 8/8, 9/9, 10/10, 11/11 i 12/12 mm. W pierwszej serii u krów mlecznych odzyskano więcej cząstek $(97,8$ vs $75,9 \%$ ) oraz istotnie krótszy był u nich średni czas przechodzenia cząstek przez przewód pokarmowy (TMRT) $(53,0$ vs 96,6 godz.) niż u krów zasuszonych $(\mathrm{P}<0,05)$. W drugiej serii, na krowach mlecznych, największe różnice stwierdzono w odzyskaniu cząstek o wielkości $11 / 11$ a $14 / 14 \mathrm{~mm}$, które było istotne po 48 godz. (63,8 vs $31,3 \%$; $\mathrm{P} \leq 0,05)$. Zwracanie cząstek o wielkości $17 / 17 \mathrm{~mm}$ w ciągu 384 godz. wynosiło $27,5 \%$ u krów mlecznych i $80 \%$ u zasuszonych. W trzeciej serii istotne różnice w odzyskaniu cząstek stwierdzono tylko po 36 godz.

Na podstawie otrzymanych wyników stwierdzono, że odzyskiwanie cząstek plastikowych oraz TMRT jest stosunkowo dobre przy wielkości cząstek większych niż $11 / 11 \mathrm{~mm}$ i mniejszych niż $14 / 14 \mathrm{~mm}$. 